\title{
Practices and Challenges of Appraising Teacher's Performance Appraisal in Government Preparatory Schools of Wolaita Zone, South Ethiopia
}

\author{
Cherenet Samuel $^{1 *} \quad$ Endale Berhanu $^{2}$ \\ 1.Corresponding author: Wolaita Sodo \\ 2.Co-author; Wolaita Sodo University
}

\begin{abstract}
The main purpose of this study was to assess the practice and challenges of appraising teachers' performance appraisal in the preparatory schools of Wolaita Zone, Southern Nations, Nationalities and People's Region. The objectives were attained by analyzing how teacher's performance is appraised, identify the methods and criteria employed in appraising teachers performance, determining the extents to which teachers performance appraisal is used and identifying the challenges encountered in appraising teachers performance in government preparatory schools of Wolaita zone. To this end, descriptive survey research design was employed. A sum of 488 teachers, 6 supervisors, 6 principals, 6 vice principals totally 506 were the target populations. Accordingly, out of 488, (122) $(25 \%)$ teachers were selected through simple random sampling technique and 6 administrative vice principals, 6principales and 6 supervisors were included based on availability sampling technique. Questionnaire and interviews were employed to collect data. The data obtained were analyzed using statistical tools such as mean, standard deviations, frequency and percentage. Accordingly, the findings revealed that the criteria was inadequate and inappropriate and describes what the teachers are, rather than what teachers do, does not measure good teaching, no capacity of measuring teacher willingness to participate in extracurricular activities, not appropriate to raise teacher professional development. The methods of performance appraisal commonly used for implementation of teacher performance in preparatory schools were summative evaluation method and check list but the other methods of teachers' performance appraisals like peer evaluation methods, self-evaluation method, and formative evaluation methods were not frequently used. the major problems encountered in appraising the performance of preparatory schools' teachers in wolaita zone were, lack of rewards for better performing teachers, lack of awareness about performance appraisal, In adequate guidance and support from higher official, and technical problems of principals for implementation. Therefore, it is recommended that, the zone and woreda education expertise, school principals, supervisors should give emphasis on the implementation of teacher performance appraisal in schools and should monitor and evaluate the practice every time and ,there is a high need for policy makers to review teachers performance appraisal system frequently.
\end{abstract}

Keywords: practice, performance appraisal, preparatory School. 1. Background of the Study

DOI: $10.7176 /$ RHSS/9-7-07

Publication date: April $30^{\text {th }} 2019$

Education plays key roles in development and it is the main instrument to solve economical, political and social problems of a country. Schools are social organizations established to facilitate the teaching learning process. In education sector, the responsible and the great assets are teachers. According to the World Bank (1991) cited in Getachew (2010) teachers are central to the delivery of quality education. In the same way, Ethiopian government acknowledged the key roles that teachers play in the provision of quality education. Since teachers are change agents in the development of knowledge, skill, attitude and act as facilitators in preparing the young generations for different responsibilities and promoters of new technological advancements, they should develop professionally throughout their life in sustainable way and their performance should be evaluated contentiously. Given that "teacher performance appraisal can be a key lever for increasing the focus on teaching quality" (OECD, 2013b, p.9) and that many reforms in the past have failed (Kleinhenz \& Ingvarson, 2004), an understanding of the various aspects of successful performance appraisal is essential. In this regard Stronge and Tucker, (2003) reported that evaluation of teachers is important because without capable, high quality teachers' classrooms, no educational development effort can possibly be successful. They further reported that the core of education is teaching and learning, which can be achieved by having effective teachers. So effective teachers can only be seen when there are high quality evaluation systems, (Stronge \& Tucker, 2003, p. 3). Therefore, teachers have to be continuously motivated and upgraded so as to achieve the goals and objective of education effectively and to improve the quality of teaching.

Performance appraisal can be defined as the ongoing process used for identifying, measuring and developing an individual's performance in accordance with an organization's strategic goals (Aguinis, 2009). The purpose of performance appraisal in school is to ensure that effective teachers continue in the classrooms, to foster professional growth of new and continuing teachers, to promote school improvement and the enhancement 
of student learning and to ensure that best qualified teachers are hired (Millman and Linda, 1990).

Appraisal may involve formative aspects that focus on developing performance, such as career development, professional learning and feedback. Summative aspects, on the other hand, evaluate performance for career progression, possible promotion or demotion and termination purposes.

Having decided the purpose of evaluation, the school must design an evaluation plan to achieve these purposes. According to Webb and Norton (1999:381), Evaluation plan has three major elements which, in effect, involve answers to three questions: what will be evaluated? (The criteria) what level of performance is expected? (The standard), and how well evidence be collected? (Media and data collected)"According to (Moorhead \& Griffin, 1992), performance appraisal was introduced in the United States of America in the 1940s during the Second World War as a method of justifying employees' salary. It was then known as merit rating. Whereas, in Ethiopia teacher performance evaluation was introduced along with the beginning of inspection in 1934 E.C for the first time as a method to control and inspect the institutional process (Hailesselassie, 1996 :12). Berhanu (2006:7) reported that, since 1995, in addition to administrative evaluation, students' and parents' evaluation of teachers' performance had been in effect at elementary and secondary government schools. Recently, since 2004 result-oriented teachers performance appraisal was introduced in line with Federal Civil Service Commission (FCSC). However, there have been problems in the implementation, thereby, many teachers complain and do not have a positive attitude toward result-oriented teacher performance appraisal (Yilma 2007).

Performance appraisal as one of the essential tool of Human Resource Management, it can have many purposes in organizations. According to Mathis and Jackson (1997: p. 344), "performance appraisal (PA) has two roles in organizations: to measure performance and development of individual potential". Consequently, PA can be an important tool for supporting and improving the quality of teaching. Unfortunately, teacher evaluation too frequently has been viewed not as vehicle for growth and improvement, but rather as a formality that must be endured (Stronge and Tucker, 1999). However, teacher performance evaluation and professional development should be viewed as the inseparable pair. Thomas (1984), "The main purpose of evaluation should be to provide information and to help teachers improve their teaching performance. Accordingly a good evaluation system should reflect respect for individual worth and dignity by encouraging teachers to set personal and organizational objectives" (p.2).

Further, a crucial element in teacher evaluation systems is its link to teacher professional development and school improvement. As Wheeler and Scriven in (2006) stated, the existence of clear criteria and standards of performance are seen as a key factor for quality teacher evaluation systems. As Iraki (2013) cited.

Performance appraisal is about documenting the quality of teachers' performance, helping them improve and hold them accountable for their work (Stronge, 2006). To this effect the importance of a quality teacher evaluation system is paramount. However, the obsolete evaluation system, exclusion of students' feedback, untrained evaluators and decreased motivation for the process are the potential hindering factors for performance appraisal systems (Rasheed, 2013). Moreover Stronge (2010) identified that performance appraisal is collaboration, cooperation, communication and commitment in disguise. All these factors contribute towards quality of teachers. In other words, if a quality system is to be developed, it is important to look at the ways in which both appraisers and appraises see the appraisal process and the association between them.

Performance appraisal is a process that involves determining and communicating to an employee how he/she performing the job and ideally establishing a plan of improvement. According to Gorton (1983) cited in Tatek (2012) recommends that principals, assistance principals, unit leaders, and department heads jointly appraise teachers. For effective Teachers' Performance Appraisal System (TPAS) to happen, school principals must ensure that these stockholders are well trained in appraisal procedures and their active participation in the process of implementation. In support of this Stronge and Tuker (1999) asserted that teachers and other stakeholders should be educated on the role, purpose and importance of evaluation as a part of their regular professional life. Hence, performance appraisal affective and clearly explained to employees, there is a high chance that it could be implemented with a high degree of importance and tolerability. According to Melaku (2000:41) multiple appraisal approach such as peer appraisal, student appraisal and self-appraisal are also vital to reduce appraisal errors and create trust and confidence in the school organization. Given these vital roles of the teacher's performance appraisal to the development of teachers and the students' achievements, the researcher was initiated to conduct this study.

\section{Statement of the Problem}

The teachers' performance appraisal is the management activities. It can be defined as the ongoing process used for identifying, Measuring and developing an individual's performance in accordance with an organization's Strategic goals (Aguinis, 2009). To this line, in schools teachers' performance appraisal is continuously undertaken to assist in identification, measurement and development of the teachers work so that the aims and objectives of the school are more effectively realized while along benefiting the teachers in terms of recognition of performance, professional advancement and career support (Schuler et al 1992; as cited by Tatek, 2014:25). 
A study carried out by Yilima 2007 on practice of teacher's performance appraisal in Halaba special Woreda primary school show that the majority of teachers in his study didn't have favourable attitudes towards TPA criteria and teachers were not fully involved in developing the appraisal criteria and teachers also complained that principals were not knowledgeable in appraising their performance.

According to Yamoah (2013), where teachers' performance appraisal is practiced properly with different motivations, teachers could perform in excellent manner. The proper development and implementation of performance appraisal can result in sustainable improvement in school organizations performance. However, "teachers' performance evaluation has not proved to be an easy task to successfully accomplish in many school systems. The task of teachers' performance evaluation has been troublesome to both teachers and their evaluators" (Melaku, 1992: 90). Whereas, according to Armstrong and Baron (2002) if the performance appraisal system of development and practice are misguided, then all efforts will remain futile exercises, which could lead to wastage of resources.

Tatek in 2012 from his study on practice of performance appraisal and teachers reaction in secondary school of Oromiya West Harage zone put some conclusion. His mixed methods study, involving interviews with 14 principals and supervisors and a survey of 145 teachers and appraisers (i.e. unit leaders, department heads, vice principal) concluded that majority of teachers are not motivated by the current practice, not satisfied with the feedback, they didn't believe the essentiality to conduct performance evaluation in their school, this results in conflict.

Moreover, teachers were not fully involved in developing the appraisal criteria. Teachers also complained that the principals were not knowledgeable in appraising their performance. However different researchers conducted their research on practice of performance appraisal, still now practice of performance appraisal in wolaita zone preparatory schools is not implemented in good manner. This is because teachers were appraised by principals alone and they have no chance of reporting their complaint upon appraisal results. Most of the time teachers were seen when they resist accepting their evaluation results. They were complaining with their principal so that it pollutes good working cultures and leads to conflict. Based on the above evidences, the researcher focused on practice of teacher's performance appraisal. That is practice and challenges of teacher's performance appraisal in government preparatory schools of wolaita zone.To address this issue the following research questions have been forwarded.

1. How teachers' performance appraisal is appraised in the government preparatory schools of wolaita zone?

2. What are the methods and criteria employed in appraising teachers' performance appraisal in government preparatory schools of wolaita zone?

3. To what extent the teacher's performance appraisal used for teachers learning and growth?

4. What are the challenges encountered in the implementation of teachers performance appraisal?

\section{Objectives of the Study \\ 3.1 General objective}

The underlying objective of this study was to look at the practice and challenges of appraising teacher's performance appraisal and to give recommendations in government preparatory schools of wolaita zone.

\subsection{Specific objectives}

Based on this general objective, this study attempts to address the following specific objectives.

1. To analyze how teacher's performance is appraised in government preparatory schools of Wolaita zone.

2. To identify the methods and criteria employed in appraising teachers performance appraisal government preparatory schools of Wolaita zone.

3. To determine the extent to which TPA is used for teachers learning and growth.

4. To identify the challenges encountered in the implementation of teachers performance appraisal.

\section{The Research Design and Methodology \\ 4.1. Research Design}

In this chapter, the research design that was used for this study is descriptive survey research design because this design is suitable to obtain sufficient information on the issue under study from relatively large number of cases at particular time. According to Isaac and Michael, (1977, p. 18), this design is used to describe systematically the facts and characteristics of a given population or area of interest, factually and accurately. Descriptive survey research design was chosen with a mix of both quantitative and qualitative approaches but more of quantitative one. Surveys are especially important in educational research to describe attitudes, beliefs, and opinions.

\subsection{Research method}

The research method which is appropriate to undertake this study was both qualitative and quantitative method. 
Within the mixed research area, the study was adopted descriptive survey design which employed sufficient questionnaires to ask teachers to provide real information about practice and challenges of teacher's performance appraisal in government preparatory school of Wolaita zone.

Both qualitative and quantitative research analysis, specific approach to its subject matter was suited the study's quest to investigate about practice and challenges of teachers performance appraisal in government preparatory schools of Wolaita zone. The researcher was choose this method because Quantitative approach is considered as appropriate because it uses the survey in collecting data from a wide area by selecting a representative sample of a large population. Besides, the qualitative approach was employed so as to obtain detailed descriptions of the phenomenon.

\subsection{Data sources}

The Data was collected by using two data sources: primary and secondary Sources. The primary sources were principals, vice principals, supervisors and teachers in those selected seven governmental preparatory school in six districts which were Boloso Bombe, Boloso Sore ,Areka city administration, Boditi city administration, Damot Sore, and Humbo Tebela. Whereas the secondary sources were performance appraisal documents in the schools.

\subsection{Population, Sample size and Sampling Technique}

The entire wolaita zone is in Southern Nation, Nationalities and People Regional State which was considered as the study area. In this zone there were twelve Woredas and three city administrations. Under those Woredas and city administrations there were about twenty-six GSPS. The researcher has selected purposefully six woredas which were, Boloso Bombe, Boloso Sore Areka city administration, Boditi city administration, Damot sore, and Humbo Tebela. In those woredas there were seven government preparatory schools, a sum of 488 teachers, 6 supervisors, 6 principals, 6 vice principals totally 506 populations were working in these government preparatory schools. Regarding the school samples, out of the existing twenty six government secondary and preparatory schools, seven schools were purposefully selected and used as data sources. This area was purposefully decided to be taken as a setting for this study because of the researcher has worked in different schools located at those Woredas of the Zone; it was helped him in the process of data collection. Since the size of selected sample school were relatively large so that the researcher used descriptive survey. According to Singh (2007, p.6) "descriptive survey research typically uses larger samples: it is suggested that the sample size should not be less than 25 percent of accessible population for the sample". Accordingly, out of 488 teachers, one Hundred twenty two (122) $25 \%$ teachers were included based on simple random sampling technique, 6 principals and 6 vice principals and 6 supervisors were included based on the availability sampling technique. Simple random sampling was employed to select appropriate teachers from total population at school, to fill the questionnaires as they have equal chance for all to be selected in order to avoid sampling bias. Simple random sampling is conducted in such a way that every person in the population has an equal and independent chance of being selected (Marguerite et al., 2006).

At school level, the researcher obtained the list of teachers from the school leaders. The names were written on pieces of papers and placed in a box. Then, the researcher picked randomly required pieces of paper. Teachers whose names were picked randomly were selected for the study. On selecting instructional leaders (principals, vice principals and supervisors) for conducting structured interview and, to fill the questionnaires purposive sampling technique was employed to select eighteen instructional leaders. The availability sampling technique has been chosen by the researcher to select instructional leaders based on their experience. This method is chosen because population of instructional leaders in all selected schools are little in number so that all of them will be included $100 \%$. Accordingly, out of 18 instructional leaders (principals, vice principals and supervisors), eighteen (18) were selected by availability sampling technique. From those selected instructional leaders 6 supervisors were interview and 6vice principals, 6principales were asked to fill questioners. 
Table.1: The total population and selected sample size

\begin{tabular}{|c|c|c|c|c|c|c|c|c|c|c|}
\hline \multirow[b]{2}{*}{$\begin{array}{l}\text { Selected } \\
\text { woredas }\end{array}$} & \multirow[b]{2}{*}{ Sample } & \multicolumn{3}{|c|}{$\begin{array}{l}\text { Teachers } \\
\text { Teachers }\end{array}$} & \multicolumn{4}{|c|}{ Instructional leaders } & \multirow[b]{2}{*}{$\frac{\frac{0}{Z}}{\tilde{Z}}$} & \multirow[b]{2}{*}{$d^{\circ}$} \\
\hline & & 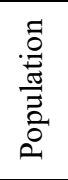 & $\frac{\stackrel{0}{\overparen{Z}}}{\overparen{\#}}$ & $\%$ & 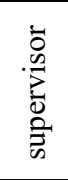 & 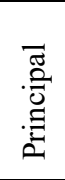 & $\begin{array}{l}\dot{\Xi} \\
\stackrel{\Xi}{0} \\
\stackrel{0}{0} \\
\dot{>}\end{array}$ & 퐁 & & \\
\hline Boloso Bombe & Bombe & 135 & 33 & 25 & 1 & 1 & 1 & 3 & 3 & 100 \\
\hline \multirow{2}{*}{ Bloso Sore } & Hembecho & 55 & 14 & 25 & 1 & 1 & 1 & 3 & 3 & 100 \\
\hline & Gurumo koysha & 52 & 13 & 25 & - & 1 & - & 1 & 1 & 100 \\
\hline $\begin{array}{l}\text { Areka city } \\
\text { administration }\end{array}$ & Areka & 64 & 16 & 25 & 1 & 1 & 1 & 3 & 3 & 100 \\
\hline $\begin{array}{l}\text { Boditi city } \\
\text { adimnistration }\end{array}$ & Boditi & 50 & 12 & 25 & 1 & 1 & 1 & 3 & 3 & 100 \\
\hline Damot sore & Gununo & 57 & 14 & 25 & 1 & 1 & 1 & 3 & 3 & 100 \\
\hline Humbo tebela & Tebela & 75 & 19 & 25 & 1 & 1 & 1 & 3 & 3 & 100 \\
\hline Total & & 488 & 122 & 25 & 6 & 6 & 6 & 18 & 18 & 100 \\
\hline $\begin{array}{l}\text { Sampling } \\
\text { techniques }\end{array}$ & \multicolumn{4}{|c|}{ Simple random sampling } & \multicolumn{6}{|c|}{ Availability sampling } \\
\hline
\end{tabular}

\subsection{Data Gathering Tools}

The researcher was use different kinds of tools to collect the necessary data for his study. The tools employed were questionnaire, interview, and document analysis. These tools were designed before the actual data collection and were presented to the advisor for improvement and then distributed to the sample population.

\subsubsection{Questionnaire}

Questionnaires were used to collect data from the teachers and instructional leaders of secondary and preparatory schools of Wlaita zone to obtain first-hand information. It was prepared by the researcher based on review of literature. The questionnaires were 36 items (33 close ended and 3 open ended) and were divided in to 5 parts. The researcher use close ended questionnaire because it is easier to analyze and does not consume more time and it does not need detail information from respondents. The researcher used open ended questionnaire to get detailed information from his respondents .The first part was prepared for respondents background information ,second part was related to the extent of teachers performance appraisal used for teachers learning and growth .The third part was designed to know how teachers performance appraisal is implemented, the fourth part was constructed to identify the criteria employed in appraising teachers performance appraisal and the fifth part was designed to identify the challenges encountered in implementation of teachers performance appraisal .Teachers, principals and vice principals filled questionnaires out of the class time without any intervention of their actual class time. This helped teachers to not waste their class time, So that the researcher used either free time or opposite shift for individual respondents to fill questioners.

\subsubsection{Interview}

The other tool that the researcher employed for gathering data was personal or individual interview. In the study, semi structured interview was conducted with the school supervisors to obtain further supplementary information which were appropriate to the study .It was helped to dig up appropriate information from the respondents. Roger (1997) clearly emphasizes the importance of interview as it is the most flexible means of obtaining information. As it gives opportunity for face-to-face interaction, details of which is not possible through questionnaire and document analysis. 5 supervisors were interviewed. It was deliberately done to maximize the reliability of the data obtained through questionnaire and document. The interview contained both structured and unstructured questions which were delivered orally and by reading the questions as a subject responds. The interviews with these groups of respondents were specifically geared towards obtaining information on to analyze the ways that TPA is implemented, to identify the methods and criteria employed, to determine the extent that TPA used for teachers learning and growth and to identify the challenges encountered in implementation of TPA. The interview was conducted to 5 supervisors in working hours at their schools in one by one through face to face and conducted by the researcher. The data was maintained during the interview are recorded through notebook.

\subsubsection{Document analysis}

Document analysis is the other essential data collecting tool. Various documents including file containing a yearly record of TPA, individual teachers' portfolios, and reports at selected preparatory schools of Wolaita Zone. The related documents were analyzed and recorded on notebook. 


\subsection{Pilot Test}

4.6.1 Validity

To improve the validity a pilot study was conducted after which responses to each item were analyzed to identify any misunderstandings and uncertainty. Items that were found to be misunderstood or uncertainty were modified thereby improving face valid. All improvements such as spelling errors and grammars were made clear based on the feedback obtained from the pilot respondents. Based on the analysis of the pilot study, some unclear and confusing items were modified to make the questionnaire clear and understandable.

Expert opinions, literature searches and pre-testing of open ended questions were used to improve content validity. Consequently, the instruments were constructed with guidance from university research Advisor; and the results of pilot study on open ended and interview questions also helped to improve content validity.

\subsubsection{Reliability}

Before the final questionnaires are administered, pilot testing was conducted in Sodo preparatory school which is not included in the sample study. It was helped to ensure that the respondents understand what the questionnaire wants to address and was done with the objectives of checking whether or not the items contained in the instruments can enable the researcher to gather relevant information, to identify and eliminate problems in collecting data from the target population. The draft questionnaires were distributed to 1 school principal, 1 vice principals, and 10 teachers of the above school which is selected purposively. After the questionnaires were filled and returned, the reliability of items were measured by using Crobanch"s alpha method by the help of SPSS version 20.

Acording to Bryman and Cramer (1990: 71) the coefficient of Alpha guidelines used as $\geq 0.90$ is very reliable

$0.80-0.90$ is highly reliable

$0.70-0.79$ is reliable

$0.60-0.69$ is minimally reliable

$\leq 0.60$ is unacceptable reliable.

The measuring instrument is reliable if it provides consistent results (Kothari: 2005). To check the reliability of the instruments used in the research, especially the close-ended questions, the Cronbach ${ }^{\text {ee }}$ Alpha model was utilized. According to my analysis the range values of cronbach alpha was ranging from 0.70 to 0.93 . Thus, the result showed the reliability of the questions.

\subsection{Procedures of Data gathering}

First, the researcher was visited the Woreda education office and discuss the purpose of the research showing the letter of cooperation from Wolaita soddo University and asked the Woreda education office to write a letter to government secondary and preparatory school in their Woreda. Then the researcher was visited the school director and vice-director and discussed the purpose of the research with principals, vice-principals and showing the letters from the University and the Woreda education Office. Then the researcher clarified the objective of the research, and asked whether the respondents were willing to the interview or not. After that the researcher was used semi structured interview so as to let the interviewee to express her/his feeling freely, let the researcher used the ideas from other source (in contrast to the well structured one) and at the same time more convenient for analysis purpose than unstructured interview(Wragg,2002). The researcher was also distributed the questionnaires to the respondent teachers and school leaders after he selected them and has given enough time to fill the questionnaires.

After fixing the sample size, 122 questionnaires were distributed to 122 teachers. Among these 117 (95.9\%) completed copies of questionnaires were returned. From the returned questionnaires 5 of them were not returned back to researcher so that the researcher rejected five questionnaires and Finally 117 (95.9\%) copies were used for entire analysis.

\subsection{Method of Data Analysis}

After the questionnaires were completed by the respondents, they were collected back and checked for completeness. Then, the items were codified and subjected to statistical procedures using Statistical Package for Social Science (SPSS) version-20. Descriptive statistics such as percentage, mean, and standard deviation were computed to see the results of research question. These methods were more suitable to get real information than the other methods and also can reduce error.

In analyzing the teachers' questionnaire, both qualitative and quantitative but more of quantitative methods were used. This is because the questioner collected from teachers school leaders were more quantitative manner .However, the data from interview and document analysis were analyzed qualitatively. As interview, and document analysis was intended for triangulating the information in the questionnaire, they were first treated together with the questionnaire. 


\subsection{Ethical Consideration}

All the research participants included in the study were duly informed about the purpose of the research so that their willingness and consent is ensured before the commencement of the study.

The study was conducted in such a way that it considered ethical responsibility that is being honest about what exactly the study is all about and what it intended to measure. The respondents were assured that the information that they provided were confidential and only used for the intended purpose. Furthermore, the researcher was selected a free and calm environment to lessen communication barriers that disturb the interviewing and discussion process.

\section{Discussions and Findings}

\subsection{Characteristics of Respondents}

After fixing the sample size, 122 questionnaires were distributed to 122 teachers. Among these 117 (95.9\%) completed copies of questionnaires were returned. From the returned questionnaires 5 of them were not returned back to researcher so that the researcher rejected five questionnaires and Finally 117 (95.9\%) copies were used for entire analysis.

Table 2: Characteristics of the respondents

\begin{tabular}{|c|c|c|c|c|c|c|c|c|}
\hline \multirow[t]{2}{*}{ No } & \multirow[t]{2}{*}{ Items } & \multirow[t]{2}{*}{ Category } & \multicolumn{2}{|c|}{ Teachers } & \multicolumn{2}{|c|}{ Principals and vice principals } & \multicolumn{2}{|c|}{ Supervisors } \\
\hline & & & $\mathrm{f}$ & $\%$ & $\mathrm{f}$ & $\%$ & $\mathrm{f}$ & $\%$ \\
\hline \multirow[t]{3}{*}{1} & \multirow[t]{3}{*}{ Sex } & Male & 85 & 72.6 & 11 & 91.7 & 6 & 100 \\
\hline & & Female & 32 & 27.4 & 1 & 8.3 & - & - \\
\hline & & Total & 117 & 100 & 12 & 100 & 6 & 100 \\
\hline \multirow[t]{4}{*}{2} & \multirow[t]{4}{*}{ Age } & $21-30$ & 37 & 31.6 & 3 & 25.0 & 2 & 33.3 \\
\hline & & $31-40$ & 67 & 57.3 & 9 & 75.0 & 4 & 66.7 \\
\hline & & 41and above & 13 & 11.1 & - & - & - & - \\
\hline & & Total & 117 & 100 & 12 & 100 & 6 & 100 \\
\hline \multirow[t]{4}{*}{3} & \multirow[t]{4}{*}{ Qualification } & Diploma & 3 & 2.6 & - & - & - & - \\
\hline & & $\mathrm{BA} / \mathrm{BED}$ & 80 & 68.3 & 1 & 8.3 & - & - \\
\hline & & MSC/MA & 34 & 29.1 & 11 & 91.7 & 6 & 100 \\
\hline & & Total & 117 & 100 & 12 & 100 & 6 & 100 \\
\hline \multirow[t]{5}{*}{4} & \multirow[t]{5}{*}{ Work load } & $8-12$ & 46 & 39.3 & - & - & - & - \\
\hline & & 14-18 & 52 & 44.4 & - & - & - & - \\
\hline & & $20-24$ & 16 & 13.7 & - & - & - & - \\
\hline & & 24andabove & 3 & 2.6 & - & - & - & - \\
\hline & & Total & 117 & 100 & - & - & - & - \\
\hline \multirow[t]{5}{*}{5} & \multirow[t]{5}{*}{ Experience } & $0-5$ & 14 & 12.0 & 4 & 33.3 & 1 & 16.7 \\
\hline & & $6-10$ & 82 & 70.1 & 2 & 16.7 & 2 & 33.3 \\
\hline & & $11-15$ & 13 & 11.1 & 6 & 50.0 & 3 & 50.0 \\
\hline & & Above 16 & 8 & 6.8 & - & - & - & - \\
\hline & & Total & 117 & 100 & 12 & 100 & 6 & 100 \\
\hline
\end{tabular}

Table 2 indicates the demographic characteristics of respondents involved in this research with respect to their gender, age, qualification, work load and experience. The table shows that out of the 117 teachers involved in this study, $85(72.6 \%)$ were male while the remaining $32(27.4 \%)$ were female. The results may suggest that the preparatory schools of Wolaita zone were dominated by men teachers. Regarding vice principals and principals $11(91.7 \%)$ were male and only $1(8.3 \%)$ female. This signifies that in preparatory schools of wolaita zone, the involvement of women's in leadership position was nonexistent and their involvement in teaching activities was very low.

Regarding the age of teachers, the table reveals that 37 (31.6\%) were within the age group 21-30 and 67 $(57.3 \%)$ were between $31-40$ years and $13(11.1 \%)$ were above 40 years. With regard to the age of respondent, Most of them were of age groups of 31-40 years of age which accounted 57.3\%). This implies that the majority of the respondents were mature enough and this may helped the researcher got organized information upon practice and challenges of teachers performance appraisal system in sample schools.

Regarding the age of instructional leaders $33.3 \%$ were within age group $21-30$ years old and $66.7 \%$ of them were with age group of 31-40.This in turn implies that all appraisers are matured enough to provide the researcher with the necessary information.

As regards to the qualification of the instructional leaders, all $(100 \%)$ of supervisors were second degree holders and regarding to principals and vice principals $8.3 \%$ of them were first degree and $91.7 \%$ were second degree holders. Hence, it was thought that the information they provide would be dependable and logical due to their academic backgrounds. Regarding to qualification of teachers, the majorities $68.3 \%$ are bachelor's degree 
holders, $29.1 \%$ were master's degree and 2.6\% are diploma holders in government preparatory schools of wolaita zone. Therefore, it is possible to conclude that the information obtained from them can be considered as a reliable and reasonable due to their academic background.

As regarding to respondents years of work experience, $14(12 \%)$ of teachers and $4(33.3 \%)$ of principals and vice principals had $0-5$ years of service, but $82(70.1 \%)$ of teachers, $2(16.7 \%)$ of principals and vice principals had 6-10 years of service, but $13(11.1 \%)$ of teachers and $6(50 \%)$ of principals and vice principals had 11-15 years of service, and $8(6.8 \%)$ of teachers had above 16 years of service. It would be, therefore, possible to infer that $66.7 \%$ of the principals and vice-principals had service years above 6 years and this rich experience might help the principals to establish and maintain good association with teachers and moreover help them to get knowledge of good teaching. On the other hand, $82.1 \%$ of the teachers had less than 11 years of service. It would be, therefore, possible to generalize from these data that such relatively less years of service in the education system might affect leaders and to evaluate teachers with rich experience and better understanding about the various issues and problems of teacher's performance appraisal in secondary schools.

Table 3: how teachers' performance appraisal implemented. $(\mathrm{N}=129)$

\begin{tabular}{|c|c|c|c|c|c|c|c|c|}
\hline \multirow[b]{2}{*}{ No } & \multirow[b]{2}{*}{ Item } & \multicolumn{7}{|c|}{ Scales } \\
\hline & & $\begin{array}{l}\text { SD } \\
\text { F } \%\end{array}$ & $\begin{array}{l}\mathrm{D} \\
\mathrm{F} \%\end{array}$ & $\begin{array}{l}\text { UD } \\
\text { F \% }\end{array}$ & $\begin{array}{ll}\mathrm{A} \\
\mathrm{F} \%\end{array}$ & \begin{tabular}{l|l} 
SA \\
F $\%$
\end{tabular} & Mean & S.D \\
\hline 1 & $\begin{array}{l}\text { Principals used checklist to asses teachers performance } \\
\text { appraisal }\end{array}$ & $\begin{array}{l}25 \\
19.4\end{array}$ & \begin{tabular}{l|l}
25 \\
19.40
\end{tabular} & $\begin{array}{l}13 \\
10.1\end{array}$ & \begin{tabular}{l|l}
37 \\
28.6
\end{tabular} & \begin{tabular}{l|l}
29 \\
22.5
\end{tabular} & 3.46 & 1.74 \\
\hline 2 & $\begin{array}{l}\text { Principals use peer-evaluation methods to assess teachers } \\
\text { performance appraisal }\end{array}$ & $\begin{array}{ll}66 \\
51.2\end{array}$ & \begin{tabular}{l|l|}
39 \\
30.2
\end{tabular} & $\begin{array}{l}12 \\
9.3\end{array}$ & \begin{tabular}{l|l}
4 \\
3.1
\end{tabular} & \begin{tabular}{l|l}
8 \\
6.2
\end{tabular} & 1.82 & 1.15 \\
\hline 3 & $\begin{array}{l}\text { Principals use self-evaluation method to assess teachers } \\
\text { performance appraisal }\end{array}$ & $\begin{array}{ll}59 \\
45.7\end{array}$ & $\begin{array}{l}24 \\
18.6\end{array}$ & $\begin{array}{l}31 \\
24\end{array}$ & $\begin{array}{ll}8 \\
6.2 \\
\end{array}$ & $\begin{array}{l}7 \\
5.4\end{array}$ & 2.06 & 1.22 \\
\hline 4 & $\begin{array}{l}\text { Principals use summative evaluation methods making major } \\
\text { decisions on teachers' performance at the end of a semester or } \\
\text { academic year }\end{array}$ & $\begin{array}{l}37 \\
28.7\end{array}$ & $\begin{array}{l}12 \\
9.3\end{array}$ & $\begin{array}{l}4 \\
3.1\end{array}$ & $\begin{array}{l}27 \\
20.9\end{array}$ & $\begin{array}{l}49 \\
38 .\end{array}$ & 3.26 & 1.7 \\
\hline 5 & $\begin{array}{l}\text { Principals' performance appraisal method leads teachers in to } \\
\text { low level of satisfaction }\end{array}$ & $\begin{array}{l}26 \\
20.2 \\
\end{array}$ & $\begin{array}{l}10 \\
7.8\end{array}$ & $\begin{array}{l}10 \\
7.8\end{array}$ & $\begin{array}{l}36 \\
27.9\end{array}$ & $\begin{array}{l}47 \\
36.3 \\
\end{array}$ & 3.52 & 1.54 \\
\hline 6 & $\begin{array}{l}\text { Principals' performance appraisal method affects individuals } \\
\text { efficiency }\end{array}$ & $\begin{array}{l}21 \\
16.2\end{array}$ & $\begin{array}{l}3 \\
2.3\end{array}$ & $\begin{array}{l}2 \\
1.6\end{array}$ & $\begin{array}{l}49 \\
38\end{array}$ & \begin{tabular}{l|l}
54 \\
41.9
\end{tabular} & 3.85 & 1.44 \\
\hline
\end{tabular}

Note: $\mathrm{SD}=$ strongly disagree, $\mathrm{D}=$ Disagree, $\mathrm{U} . \mathrm{D}=$ Undecided $\mathrm{A}=$ Agree and $\mathrm{SA}=$ strongly agree, $\mathrm{S} . \mathrm{D}=$ standard deviation

As indicated in the item 1, in Table 3, the respondents were asked to rate their views on whether Principals used checklist to asses teachers performance appraisal.Accordingly, 37(28.7\%) of respondents rated on agree and $29(22.5 \%)$ of respondents rated on strongly agree with mean value of 3.46 and standard deviation of 1.74 respectively. This verifies that the leaders in sample preparatory schools of wolaita zone were used check list to assess teacher's performance appraisal.

In Table 3, item 2, the respondents were requested to rate whether Principals use peer-evaluation methods to assess teacher's performance appraisal. Based on this, 66(51.2\%) of respondents labelled on strongly disagree and $39(30.2 \%)$ of respondents labelled on disagree, $12(9.3 \%), 4(3.1 \%), 8(6.2 \%)$ were answered back as undecided, agree and strongly agree respectively with mean and standard deviation of 3.12, 0.97 respectively. This shows that peer evaluation methods were not commonly used in selected preparatory schools

According to the finding discussed under item 3 of table 3,59(45.7\%) and 24(18.6\%) considerable number of respondents strongly disagreed and disagreed on that Principals use self-evaluation method to assess teacher's performance appraisal. The others $31(24.0 \%), 8(6.2 \%), 7(5.4 \%)$ respondents labelled on undecided, agree and strongly agree respectively with mean and standard values of 2.06 and 1.22 respectively. This shows that self evaluation methods were not commonly used in selected preparatory schools of wolaita zone.

Under table 3 item 4, Participants of the study were asked about the Principals use summative evaluation method to make major decisions on teachers' performance at the end of a semester or academic year. Majority of $49(38.9 \%)$ and $27(20.9 \%)$ respondents replied as strongly agreed and agreed respectively. The others $37(28.7 \%)$, $12(5.6 \%), 4(3.1 \%)$ replied as strongly disagree, disagree and undecided respectively with mean and standard values of 1.7 and 1.45. This shows that Principals use summative evaluation methods to make major decisions on teachers' performance at the end of a semester or academic year in preparatory schools.

In table 3item 5, respondents of the study were asked to give their response on Principals' performance appraisal method leads teachers in to low level of satisfaction or not. So that $47(36.4 \%)$ and $36(27.9 \%)$ of respondents have responded as agreed and strongly agreed with mean and standard value of 3.52 and 1.54 respectively. This result reveals that performance appraisal method used in those sample schools were lead teachers in to low level of satisfaction.

As can be seen from table 3 item 6, the respondents gave their response to the question "Does the 
Principals' performance appraisal method affects individual's efficiency. And according to the above table $49(38 \%)$ of respondents chosen agree and $54(41.9 \%)$ of respondents chosen strongly agree but $21(16.2 \%)$, $3(2.3 \%), 2(1.6 \%)$ of respondents chose strongly disagree, disagree and undecided respectively. This shows that the majority of the respondents were agreed with that performance appraisal method affects individual's efficiency.

From open ended questions one of the teachers from school A, said that 'most of the time instructional leaders of their school not evaluating them on time even though they appraise, the methods of appraisal used to evaluate teachers in his school was only summative evaluation method with checklist and no other methods were applied in school'.

Performance appraisal is conducted in organizations at different intervals based on their stated internal policies. According to Webb and Norton (1992) and Duke (1995), the two common approaches are termed as formative and summative evaluations. Formative evaluation is mainly focused on providing teachers with feedbacks which are meant to improve their day-to-day performance in their profession which focuses on tracking their progress towards meeting organizational goals whereas summative evaluation is geared towards making major decisions on teachers' performance at the end of a semester or academic year. Based on literature both evaluations were very important but according to majority of respondent's preparatory schools of wolaita zone has low implementation of these approaches.

Table 4: Respondents View on the teacher's performance appraisal. N=129

\begin{tabular}{|c|c|c|c|c|c|c|c|c|}
\hline & \multirow[b]{2}{*}{ Item } & \multicolumn{7}{|c|}{ Scales } \\
\hline & & $\begin{array}{l}\mathrm{VH} \\
(\%)\end{array}$ & \begin{tabular}{l|l}
$\mathrm{H}$ \\
$(\%)$
\end{tabular} & $\begin{array}{l}\mathrm{M} \\
(\%)\end{array}$ & \begin{tabular}{l|l}
$\mathrm{L}$ \\
$(\%)$
\end{tabular} & $\begin{array}{l}\mathrm{VL} \\
(\%)\end{array}$ & Mean & S.D \\
\hline 1 & Leaders appraise teachers for motivation & $\begin{array}{l}29 \\
22.4\end{array}$ & $\begin{array}{l}18 \\
14\end{array}$ & $\begin{array}{c}16 \\
12.4\end{array}$ & $\begin{array}{l}36 \\
27.9\end{array}$ & \begin{tabular}{l|l}
30 \\
23.3
\end{tabular} & 3.89 & 1.53 \\
\hline 2 & Leaders appraise teachers for professional advancement & $\begin{array}{ll}42 \\
32.6\end{array}$ & \begin{tabular}{l|l}
31 \\
24.0
\end{tabular} & \begin{tabular}{l|l}
37 \\
28.7
\end{tabular} & \begin{tabular}{l|l}
9 \\
7.0
\end{tabular} & \begin{tabular}{l|l}
10 \\
7.8
\end{tabular} & 2.33 & 1.22 \\
\hline 3 & $\begin{array}{l}\text { Leaders have tendency to appraising teachers' performance } \\
\text { periodically for their salary increment }\end{array}$ & $\begin{array}{ll}50 \\
38.8\end{array}$ & \begin{tabular}{l|l}
50 \\
38.8
\end{tabular} & \begin{tabular}{l|l}
14 \\
10.9
\end{tabular} & $\begin{array}{ll}6 \\
4.7\end{array}$ & $\begin{array}{l}9 \\
7.0\end{array}$ & 1.81 & 0.98 \\
\hline 4 & Leaders appraise teachers for recognition of performance & $\begin{array}{l}73 \\
56.6\end{array}$ & \begin{tabular}{l|l}
40 \\
31.0
\end{tabular} & \begin{tabular}{l|l}
9 \\
7.0
\end{tabular} & $\begin{array}{l}2 \\
1.6\end{array}$ & $\begin{array}{l}5 \\
3.9\end{array}$ & 1.65 & 0.96 \\
\hline 5 & $\begin{array}{l}\text { Leaders arrange discussion sessions after class observation } \\
\text { among teachers to identify the training needs }\end{array}$ & $\begin{array}{l}59 \\
45.7\end{array}$ & \begin{tabular}{l|l}
33 \\
25.6
\end{tabular} & \begin{tabular}{l|l}
26 \\
20.2
\end{tabular} & $\begin{array}{l}5 \\
3.9\end{array}$ & $\begin{array}{ll}5 \\
4.7\end{array}$ & 1.96 & 1.11 \\
\hline 6 & $\begin{array}{l}\text { Leaders stimulate teachers to think consciously about learning } \\
\text { and growth }\end{array}$ & $\begin{array}{l}56 \\
43.4\end{array}$ & \begin{tabular}{l|l}
56 \\
43.4
\end{tabular} & $\begin{array}{l}7 \\
5.4 \\
\end{array}$ & $\begin{array}{l}5 \\
3.9 \\
\end{array}$ & $\begin{array}{l}5 \\
3.9 \\
\end{array}$ & 2.02 & 1.15 \\
\hline 7 & $\begin{array}{l}\text { Leaders appraise teachers for the purpose of only reporting for } \\
\text { higher bodies }\end{array}$ & $\begin{array}{l}13 \\
10.1\end{array}$ & \begin{tabular}{l|l}
11 \\
8.5
\end{tabular} & $\begin{array}{l}1 \\
0.8\end{array}$ & $\begin{array}{l}20 \\
15.5\end{array}$ & $\begin{array}{l}84 \\
65.1\end{array}$ & 4.17 & 1.37 \\
\hline
\end{tabular}

Note: $\mathrm{VL}=$ Very low, $\mathrm{L}=$ Low, $\mathrm{M}=$ Moderate, $\mathrm{H}=$ High and $\mathrm{VH}=$ Very high, $\mathrm{S} . \mathrm{D}=$ standard deviation

As depicted in Table 4, item 1 had asked that respondents whether the leaders appraise teachers for motivation or not. So that $36(27.9 \%)$ and $30(23.3 \%)$ of respondents marked on high and very high with mean and standard deviation of 3.89 and 1.53 respectively. This points out that the Extent of Teacher's Performance Appraisal used for teachers learning and growth in wolaita zone preparatory schools was for the purpose of motivation or career structure only.

On table 4, item 2, the respondents were asked to rate Leaders appraise teachers for professional advancement. In view of that, $42(32.6 \%)$ of teacher respondents said the Leaders appraise teachers for professional advancement as very low level and $37(28.7 \%)$ of teacher participants marked on moderate with mean and standard deviation of 2.33 and 1.22 respectively. This shows that the extent of which teachers performance appraisal has been serving in sample preparatory schools of wolaita zone were somewhat deviated from performance appraisal purpose because Leaders not appraise teachers for professional advancement.

On table 4, item 3, respondents were requested to rate leaders have tendency to appraising teachers' performance periodically for their salary increment. Accordingly, 50(38.8\%) and50 (38.8\%) of respondents were answered as very low and low respectively with mean and standard deviation of 1.81 and 0.98 respectively. This shows that leaders do not apprise teachers for the purpose of salary increments.

Item 4, on Table 4, show Leaders appraise teachers for recognition of their performance. Accordingly, $73(56.6 \%)$ of respondents said very low and $40(31.0 \%)$ of respondents said low with mean and standard deviation values of 1.65 and 0.96 respectively. This demonstrates that leaders do not appraise teachers for recognition of their performance.

On table 4, item 5, respondents were requested to rate leaders arrange discussion sessions after class observation among teachers to identify the training needs. Accordingly, 59(45.7\%) an33(25.6\%) of teachers respondents were answered as very low and low respectively with mean and standard deviation of 1.81 and 0.98 
respectively. This shows that there was no discussion session after classroom observation to excavate training needs as well as no feed back or reflection was given to appraisal teachers.

As can be seen from table 4 item 6 the respondents gave their response to Leaders stimulate teachers to think consciously about learning and growth. And the above table shows $56(43.4 \%)$ chose very low and $56(43.4 \%)$ of respondents had chosen low. This shows that the majority of the respondents were low with the idea that leaders stimulate teachers to think consciously about learning and growth.

As can be seen from the Table 4, item 7, the respondents gave their response to the question for "Principals appraise teachers for the purpose of only reporting for higher bodies" and the above table shows that $20(15.5 \%)$ of respondents chosen high and $84(65.1 \%)$ of respondents said very high. This shows that most of the respondents accept that teachers' performance appraisal is in their school only for reporting higher bodies.

As shown in literature, according to McGregor (2007) the purpose of performance appraisals can be used for administrative reasons to provide an orderly way of determining promotion transfers and salary increment .therefore the extent of TPA used for teachers learning and growth in wolaita zone as shown by respondents was low.

Table 5: Respondents response on types of Criteria Employed in appraising TPA.N=129

\begin{tabular}{|c|c|c|c|c|c|c|c|c|}
\hline \multirow[t]{2}{*}{ No } & \multirow[b]{2}{*}{ Item } & \multicolumn{7}{|c|}{ Scales } \\
\hline & & \begin{tabular}{l|l}
$\mathrm{SD}$ \\
$\mathrm{F} \%$
\end{tabular} & $\begin{array}{ll}\mathrm{D} \\
\mathrm{F} \% \\
\end{array}$ & $\begin{array}{l}\text { UD } \\
\text { F } \%\end{array}$ & $\begin{array}{l}\text { A } \\
\mathrm{F} \%\end{array}$ & $\begin{array}{l}\text { SA } \\
\text { F } \%\end{array}$ & Mean & S.D \\
\hline 1 & $\begin{array}{l}\text { School leaders use result-based plan to appraise teachers } \\
\text { performance to achieve certain objectives }\end{array}$ & \begin{tabular}{l|l}
17 \\
13.2
\end{tabular} & \begin{tabular}{l|l}
26 \\
20.2
\end{tabular} & $\begin{array}{l}10 \\
7.8\end{array}$ & \begin{tabular}{l|l|l|l}
41 \\
31.8
\end{tabular} & \begin{tabular}{l|l}
35 \\
27.1
\end{tabular} & 3.38 & 1.43 \\
\hline 2 & $\begin{array}{l}\text { Principals use performance-based criteria to assess teachers } \\
\text { behaviour to do specific tasks }\end{array}$ & \begin{tabular}{l|l}
67 \\
51.9
\end{tabular} & \begin{tabular}{l|}
16 \\
12.4
\end{tabular} & $\begin{array}{l}26 \\
20.2\end{array}$ & $\begin{array}{l}4 \\
3.1\end{array}$ & \begin{tabular}{l|l}
16 \\
12.4
\end{tabular} & 1.69 & 1.70 \\
\hline 3 & $\begin{array}{l}\text { Principals use Continuous professional development as criteria to } \\
\text { asses teachers performance }\end{array}$ & \begin{tabular}{l|l}
36 \\
27.9
\end{tabular} & \begin{tabular}{l|l}
17 \\
13.2
\end{tabular} & $\begin{array}{l}7 \\
5.4\end{array}$ & $\begin{array}{l}24 \\
18.6\end{array}$ & $\begin{array}{l}45 \\
34.9\end{array}$ & 2.13 & 1.44 \\
\hline
\end{tabular}

Note: $\mathrm{SD}=$ strongly disagree, $\mathrm{D}=$ Disagree UD undecided, $\mathrm{A}=$ Agree and $\mathrm{SA}=$ Strongly agree, $\mathrm{S} . \mathrm{D}=\mathrm{standard}$ deviation

As it can be seen from table 5, on item 1, the respondents gave their response to the question for School leaders use result-based plan to appraise teacher's performance to achieve certain objectives. They answered back with that of $41(31.8 \%)$ respondents agreed and $35(27.1 \%)$ of respondents strongly agreed. On the other hand 17(13.2\%) strongly disagreed, 26(20.2\%) said disagree and 10(7.8\%) said undecided with mean and standard deviation value $3.83,1.43$ respectively. This indicates that leaders in sample schools were use result based criteria to appraise teacher's performance.

According to item 2, in the table 5 the respondent's response on Principals use performance-based criteria to assess teacher's behaviour to do specific tasks, $67(51.9 \%)$ respondents strongly disagreed and $16(12.4 \%)$ disagreed on the statement. In combination about $26(20.2 \%)$ respondent's replied as undecided on the statement and $4(3.1 \%)$ and $16(12.4 \%)$ of respondents agreed and strongly agreed respectively on the same statement with mean standard values of 1.69 and 1.70.as indicated under above table the values indicates that leaders of sample schools were use performance-based criteria to assess teachers behaviour to do specific tasks.

As depicted on table 5 items 3 there is more than enough evidence to suggest that the schools leaders use Continuous professional development as criteria to assess teacher's performance. This was established based on the finding that about $45(34.9 \%)$ strongly agreed to the statement that Principals use Continuous professional development as criteria to asses teachers performance. Moreover, 36(27.9\%) and 17(13.2\%) of respondents strongly disagree and disagree respectively. the rest of $7(5.4 \%)$ and $24(18.6 \%)$.of respondents also shown undecided and agreed on the statement with mean and standard values of 2.13 and 1.4 respectively. That implies that principal's use Continuous professional development as criteria to assess teachers.

From interview obtained from one of supervisor said that " most of school principal do not

use appropriate criteria that can measure teachers work fairly and equally so teachers were not pleasant on their criteria used in their school because the criteria used was more of result oriented". 
Table.6: Criteria used in school to evaluate teachers' performance appraisal. N=129

\begin{tabular}{|c|c|c|c|c|c|c|c|c|}
\hline & \multirow[b]{2}{*}{ Item } & \multicolumn{7}{|c|}{ Scales } \\
\hline & & $\begin{array}{l}\mathrm{SD} \\
\mathrm{F} \%\end{array}$ & \begin{tabular}{|l|}
$\mathrm{D}$ \\
$\mathrm{F} \%$
\end{tabular} & \begin{tabular}{|l|} 
UD \\
F $\%$
\end{tabular} & $\begin{array}{l}\mathrm{A} \\
\mathrm{F} \%\end{array}$ & $\begin{array}{l}\text { SA } \\
\text { F } \%\end{array}$ & Mean & S.D \\
\hline 1 & Criteria is available in the school & $\begin{array}{l}13 \\
10.1\end{array}$ & \begin{tabular}{l|}
5 \\
3.9
\end{tabular} & $\begin{array}{c}8 \\
6.2\end{array}$ & $\begin{array}{l}35 \\
27.1\end{array}$ & $\begin{array}{l}68 \\
52.7\end{array}$ & 4.09 & 1.29 \\
\hline 2 & The criteria in school are clear & $\begin{array}{l}54 \\
41.9\end{array}$ & $\begin{array}{l}22 \\
17.1\end{array}$ & $\begin{array}{l}27 \\
20.9\end{array}$ & \begin{tabular}{l|}
2 \\
1.6
\end{tabular} & \begin{tabular}{l|}
24 \\
18.6
\end{tabular} & 2.36 & 1.49 \\
\hline 3 & The criteria measures good teaching & $\begin{array}{l}50 \\
40.3 \\
\end{array}$ & \begin{tabular}{l|}
36 \\
24.8
\end{tabular} & \begin{tabular}{|l|}
5 \\
3.9 \\
\end{tabular} & \begin{tabular}{l|}
14 \\
10.9
\end{tabular} & \begin{tabular}{l|}
26 \\
20.2
\end{tabular} & 2.43 & 1.56 \\
\hline 4 & $\begin{array}{l}\text { The criteria describe what the teachers are, rather than what the } \\
\text { teacher's dos. }\end{array}$ & $\begin{array}{l}58 \\
40.0\end{array}$ & \begin{tabular}{l|l}
1 \\
0.8
\end{tabular} & $\begin{array}{l}30 \\
23.3\end{array}$ & \begin{tabular}{l|l}
22 \\
17.1
\end{tabular} & \begin{tabular}{l|l}
18 \\
14.0
\end{tabular} & 2.36 & 1.55 \\
\hline 5 & $\begin{array}{l}\text { Teachers be significantly involved in the process of developing } \\
\text { criteria }\end{array}$ & $\begin{array}{l}80 \\
62\end{array}$ & $\begin{array}{l}5 \\
3.9\end{array}$ & $\begin{array}{l}27 \\
20.9\end{array}$ & \begin{tabular}{l|l}
9 \\
7
\end{tabular} & \begin{tabular}{l|l}
8 \\
6.2
\end{tabular} & 1.74 & 1.22 \\
\hline 6 & $\begin{array}{l}\text { Measure teachers willingness to participate in extracurricular } \\
\text { activities }\end{array}$ & $\begin{array}{l}7 \\
5.4\end{array}$ & \begin{tabular}{l|l}
34 \\
26.4
\end{tabular} & \begin{tabular}{l|l}
48 \\
37.2
\end{tabular} & \begin{tabular}{l|l}
29 \\
22.5
\end{tabular} & $\begin{array}{l}11 \\
8.5\end{array}$ & 2.63 & 1.29 \\
\hline 7 & Criteria is appropriate to raise teachers professional development & $\begin{array}{l}49 \\
38.0 \\
\end{array}$ & $\begin{array}{l}42 \\
32.6\end{array}$ & $\begin{array}{l}4 \\
3.1 \\
\end{array}$ & $\begin{array}{l}14 \\
10.9\end{array}$ & \begin{tabular}{l|l}
20 \\
15.5
\end{tabular} & 2.35 & 1.41 \\
\hline 8 & $\begin{array}{l}\text { Performance appraisal criteria is explained before appraisal takes } \\
\text { place }\end{array}$ & $\begin{array}{l}14 \\
10.9\end{array}$ & \begin{tabular}{l|l}
60 \\
46.5 \\
\end{tabular} & $\begin{array}{l}11 \\
8.5\end{array}$ & \begin{tabular}{l|l|}
30 \\
23.3 \\
\end{tabular} & \begin{tabular}{l|l}
14 \\
10.9
\end{tabular} & 2.33 & 1.46 \\
\hline
\end{tabular}

Note: $\mathrm{SD}=$ strongly disagree, $\mathrm{D}=$ Disagree, $\mathrm{UD}$ undecided, $\mathrm{A}=$ Agree and $\mathrm{SA}=$ strongly agree, $\mathrm{S} . \mathrm{D}=$ standard deviation.

As illustrated on item 1, table 6 an adequate evidence to suggest that is $68(52.7 \%)$ of respondents strongly agreed and $35(27.1 \%)$ of respondents agreed on idea that their schools have teachers performance appraisal criteria. On the other hand, 13(10.1\%) and 5(3.9\%) of respondents were strongly disagreed and disagreed on the availability of performance criteria in their schools moreover, $8(6.2 \%)$ of respondents marked as undecided on the same idea with mean and standard values 4.09 and 1.29 respectively. From this evidence it is possible to say each school of study have availability of performance appraisal criteria. This condition was also clearly seen through document investigation using check list.

As can be seen in the same table 6, item 2 above, respondents were asked to show their opinion on clarity of performance appraisal criteria in schools. Accordingly, 57 (41.9\%) respondents strongly disagreed and $22(17.1 \%)$ of respondents disagreed on the statement with mean and standard value 2.36 and 1.49 respectively. This explains that PA criteria used to appraise teachers' performance are perceived as not clear in preparatory schools of wolaita zone.

On Table 6, item 3, asks respondents whether the criteria in your school measures good teaching or not. In view of that, $50(40.3 \%)$ of respondents rated strongly disagreed on the statement and $36(24.6 \%)$ of respondents disagreed on the same statement. in addition $5(3.9 \%), 14(10.9 \%)$ and $26(20.2 \%)$ of respondents rated as undecided, agreed and strongly agreed with mean and standard values of 2.43, 1.56 respectively. This indicates that performance criteria used in school do not measure good teaching.

Regarding to table 6 item 4, the respondents gave their response to question "the criteria describe what the teachers are, rather than what the teacher dose', $58(40.0 \%)$ of respondents chosen strongly disagreed, however $30(23.3 \%)$ of respondents chose undecided and $22(17.1 \%)$ and $18(14 \%)$ of respondents chose agree and strongly agree with mean value of 2.36. The extensive research indicating that the teacher may be the primary influence on student learning within the school has placed much emphasis on teaching activities as criteria for appraisal. Teaching as a behaviour related to producing student learning is the essential focus of teacher evaluation (Harris, 1986). As George (1987) observes teachers personal traits, beliefs, and habits outside the classroom are not a central part of the job.

On Table 6, item 5, respondents were requested to rate whether Teachers be significantly involved in the process of developing criteria. Accordingly, the mean and standard deviation of the response of respondents were 1.74 and 1.22 respectively. In addition to this, the result revealed that $80(62.0 \%)$ of respondents rated strongly disagree and $27(20.9 \%)$ chose undecided. This identifies that most of teacher's do not involved in the process of developing performance criteria. This is because the process of appraising teachers' performance in preparatory schools was given to leaders as the ordinary responsibility of principals and vice principals.

On Table 6, item 6, asks respondents that whether the criteria used in schools Measure teacher's willingness to participate in extracurricular activities or not. In view of that, 48(37.2\%) of respondents rated undecided and $34(26.4 \%)$ of respondents rated as disagree with the mean and standard deviation of this item were 2.63 and 1.29 respectively. This identifies most of respondents were in doubt for willingness to participate in extracurricular activities. 
In table 6 item $7,49(38.0 \%)$ of respondents were apprises strongly disagreed about the Criteria is appropriate to raise teachers professional development. more over 42(32.6\%) of respondents given their response as disagree on the same item with mean value of 2.35. As a result, it would be possible to generalize that the criteria recently used in those schools was not appropriate to raise teachers professional development.

Related to table 6 item 8, $60(46.5 \%)$ respondent disagreed as Performance appraisal criteria is explained before appraisal takes place, on the other hand $30(23.3 \%)$ of respondents agreed on the same item with mean value of 2.33.This implies, that teachers 'Performance appraisal criteria is not explained before appraisal takes place.

This idea was also supported by the interviewed supervisors from one of the school which made it clear that, "the performance appraisal criteria was not developed and sent to schools from higher bodies, principals" no teachers were participated in the preparation". This perception declares both teachers and principals lack opportunities for participating in developing and reviewing the standards. Almost all schools principals stated that "appraisal criteria was designed by the principals and vice principals in referring duties and responsibilities of teachers and other related teaching principles".

Therefore as shown by majority of respondents Criteria used in school to evaluate teachers' performance appraisal do not measure good teaching and had nonexistent involvement of stakeholders in teacher's performance appraisal. Therefore Criteria used in school to evaluate teachers' performance appraisal in wolaita zone was weak.

Table.7: Challenges Encountered in the Implementation of TPA.N=129

\begin{tabular}{|c|c|c|c|c|c|c|c|c|}
\hline & \multirow[b]{2}{*}{ Item } & \multicolumn{7}{|c|}{ Scales } \\
\hline & & $\begin{array}{l}\text { SD } \\
\text { F } \%\end{array}$ & $\begin{array}{l}\mathrm{D} \\
\mathrm{F} \%\end{array}$ & $\begin{array}{l}\text { UD } \\
\text { F \% }\end{array}$ & $\begin{array}{l}\text { A } \\
\mathrm{F} \%\end{array}$ & $\begin{array}{l}\text { SA } \\
\mathrm{F} \%\end{array}$ & Mean & S.D \\
\hline 1 & $\begin{array}{l}\text { School principal's occupied by routine } \\
\text { administrative work }\end{array}$ & $\begin{array}{l}14 \\
10.9\end{array}$ & $\begin{array}{l}13 \\
9.9\end{array}$ & $\begin{array}{l}10 \\
7.5\end{array}$ & $\begin{array}{l}32 \\
25.3\end{array}$ & $\begin{array}{l}60 \\
46.5\end{array}$ & 3.78 & 1.43 \\
\hline 2 & $\begin{array}{l}\text { Appraisers' lack of awareness about } \\
\text { performance appraisal }\end{array}$ & $\begin{array}{l}7 \\
5.4\end{array}$ & & $\begin{array}{l}6 \\
4.7\end{array}$ & $\begin{array}{l}46 \\
35.7\end{array}$ & $\begin{array}{l}70 \\
54.3\end{array}$ & 4.29 & 1.06 \\
\hline 3 & $\begin{array}{l}\text { Technical problems of principals for } \\
\text { implementation }\end{array}$ & $\begin{array}{l}10 \\
7.8\end{array}$ & $\begin{array}{ll}3 \\
2.3\end{array}$ & $\begin{array}{ll}5 \\
3.9\end{array}$ & $\begin{array}{ll}61 \\
47.3\end{array}$ & $\begin{array}{ll}50 \\
38.8\end{array}$ & 4.04 & 1.14 \\
\hline 4 & $\begin{array}{l}\text { In adequacy and inappropriateness of } \\
\text { appraisal criteria }\end{array}$ & $\begin{array}{ll}6 \\
4.7 \\
\end{array}$ & $\begin{array}{ll}3 \\
2.3 \\
\end{array}$ & $\begin{array}{ll}23 \\
17.8 \\
\end{array}$ & $\begin{array}{ll}20 \\
15.5\end{array}$ & $\begin{array}{ll}77 \\
59.7\end{array}$ & 4.23 & 1.13 \\
\hline 5 & $\begin{array}{l}\text { Lack of positive perception of teachers about } \\
\text { teachers performance appraisal }\end{array}$ & $\begin{array}{l}20 \\
15.5\end{array}$ & $\begin{array}{l}15 \\
11.6\end{array}$ & $\begin{array}{ll}6 \\
4.7 \\
\end{array}$ & $\begin{array}{l}39 \\
30.2\end{array}$ & $\begin{array}{l}49 \\
38.0\end{array}$ & 3.66 & 1.45 \\
\hline 6 & $\begin{array}{l}\text { In adequate guidance and support from higher } \\
\text { official }\end{array}$ & $\begin{array}{l}7 \\
5.4 \\
\end{array}$ & $\begin{array}{l}7 \\
5.4 \\
\end{array}$ & $\begin{array}{l}63 \\
48.8 \\
\end{array}$ & $\begin{array}{l}4 \\
3.1 \\
\end{array}$ & $\begin{array}{l}48 \\
37.2 \\
\end{array}$ & 4.05 & 1.09 \\
\hline 7 & $\begin{array}{l}\text { Lack of rewards for better performing } \\
\text { teachers }\end{array}$ & $\begin{array}{l}4 \\
3.1 \\
\end{array}$ & $\begin{array}{ll}5 \\
3.9\end{array}$ & $\begin{array}{ll}1 \\
0.8\end{array}$ & $\begin{array}{ll}28 \\
21.7\end{array}$ & $\begin{array}{l}91 \\
70.5\end{array}$ & 4.50 & 0.97 \\
\hline 8 & The resistant of teachers to accept change & $\begin{array}{l}4 \\
3.1\end{array}$ & $\begin{array}{l}77 \\
59.7\end{array}$ & $\begin{array}{l}20 \\
15.5\end{array}$ & $\begin{array}{l}25 \\
19.4\end{array}$ & $\begin{array}{l}3 \\
2.3\end{array}$ & 2.12 & 1.03 \\
\hline
\end{tabular}

Note: $\mathrm{SD}=$ strongly disagree, $\mathrm{D}=$ Disagree, $\mathrm{UD}=$ undecided, $\mathrm{A}=$ Agree and $\mathrm{SA}=$ strongly agree, $\mathrm{S} . \mathrm{D}=$ standard deviation

The above table 7, attempts to find out the challenges encountered in the implementation of teacher's performance appraisal system in preparatory schools of wolaita zone. In order to run good implementation of performance appraisal system in the school the challenges which affect the implementation of performance appraisal system should be identified and measure should be taken on those factors. Schools may use accurate instruments for evaluating its teacher performance but there must be skilled evaluators with the necessary knowledge, skill and experience in relation to evaluating the performance of teachers.

According to table 7, item 1, asks respondents to indicate that 'School principal's occupied by routine administrative work as major challenges '.In this regard $60(46.5 \%)$ of respondents strongly agreed and $32(25.3 \%)$ were agreed on statement .on the other hand $14(10.9 \%), 13(9.9 \%)$ and $10(7.5 \%)$ of respondents replied as strongly disagreed, disagreed and undecided with mean and standard values of 3.78 and 1.43 respectively. This implies that School principal's occupied by routine administrative work as challenges that can affects implementation of performance appraisal system in schools.

Above table 7, items 2, asked respondents to indicate their agreement on lack of awareness about performance appraisal appraisers 'as challenges. Accordingly, 70(54.3\%) and 46(35.7\%) respondents indicated as strongly agree and agree respectively with mean value of 4.29. This implies that appraisers lack the necessary awareness about performance appraisal.

Again on item 3, table 7, 61(47.3\%) respondent agreed on technical problems of principals was one the 
factor for implementation of teacher's performance appraisal. In the same way 50(38.8\%) respondents strongly agreed on the same statement with mean value of 4.04.acording to above response it is possible to say technical problems of principals was one of the factors which negatively affects implementation of appraisal.

As it can be seen on item 4, table 7, 77(59.7\%) respondents strongly agreed on in competence and inappropriateness of appraisal criteria and about 20(15.5\%) respondents agreed on the statement with mean value of this item constitutes 4.23. This implies that, the majority of respondents confirmed that in their schools there was incompetence and inappropriateness of appraisal criteria.

Item 5, in Table 7, show $49(38.0 \%)$ and $39(30.2 \%)$ of respondents replied as strongly agreed and agreed respectively with mean value of 3.66 on statement. In view of that there is lack of positive perception of teachers about teacher's performance appraisal.

On Table 7, item 6, the respondents were requested to rate on in adequate guidance and support from higher officials as a challenge of performance appraisal. Consequently, the mean response was 4.05 with standard deviation of 1.09 ; whereas $63(48.8 \%)$ of respondents revealed they undecided and $48(37.2 \%)$ of respondents revealed they strongly agreed. This shows that the majority of the respondents were neutral.

As can be seen from table 7, item 7, the respondents gave their response to the item of lack of rewards for better performing teachers. The above table shows that $91(70.5 \%)$ of the respondents strongly agreed and $28(21.7 \%)$ of respondents chose agree with mean value of 4.50 . This shows that there was lack of rewards for better performing teachers in those sample schools.

As can be seen from table 7 item 8, the respondents were asked to give response on question 'there is resistance of teachers to accept change.' Accordingly, the mean and standard deviation of the response of respondents were 2.12 and 1.03 respectively. In addition to this, the result revealed that $77(59.7 \%)$ of respondents rated disagreed and 20(15.5\%) chose undecided. This identifies that most of teacher's do not agree on the idea that teachers resist the change so it could not be performance appraisal challenges.

According to interview on problems of performance appraisal most of respondents said that major problems were appraisers biased on relationship, the school performance practice no known schedule, the inadequacy and in appropriateness of the appraisal criteria, poor administration of the overall appraisal process lack of necessary knowledge, skill and experience of appraisal system.

Table.8: The challenges that affect the practice of teacher's performance in schools. $\mathrm{N}=129$

\begin{tabular}{|l|l|l|l|l|}
\hline No & Challenges that Affect Teachers performance appraisal implementation. & Mean & S.D & Rank \\
\hline 1 & School principal's occupied by routine administrative work & 3.78 & 1.43 & $6^{\text {th }}$ \\
\hline 2 & Appraisers' lack of awareness about performance appraisal & 4.29 & 1.06 & $2^{\text {nd }}$ \\
\hline 3 & Technical problems of principals for implementation & 4.04 & 1.14 & $5^{\text {th }}$ \\
\hline 4 & In adequacy and inappropriateness of appraisal criteria & 4.23 & 1.13 & $3^{\text {rd }}$ \\
\hline 5 & Lack of positive perception of teachers about teachers performance appraisal & 3.66 & 1.45 & $7^{\text {th }}$ \\
\hline 6 & In adequate guidance and support from higher official & 4.05 & 1.09 & $4^{\text {th }}$ \\
\hline 7 & Lack of rewards for better performing teachers & 4.50 & 0.97 & $1^{\text {st }}$ \\
\hline 8 & The resistant of teachers to accept change & 2.12 & 1.03 & $8^{\text {th }}$ \\
\hline
\end{tabular}

Table 8, indicates challenges that negatively affect implementation of teacher's performance appraisal system in preparatory schools of wolaita zone. In this regard, respondents were asked to respond on the challenges using Likert scales. Then, the average response rate was calculated and ranked based on the magnitude of the mean or average response of respondents.

Based on the responses provided in Table 8, the following were top seven challenges that negatively affected implementation of teacher's performance appraisal system.

1. Lack of rewards for better performing teachers.

2. Appraisers' lack of awareness about performance appraisal.

3. In adequacy and inappropriateness of appraisal criteria.

4. In adequate guidance and support from higher official.

5. Technical problems of principals for implementation.

6. School principal's occupied by routine administrative work.

7. Lack of positive perception of teachers about teachers performance appraisal.

\section{Depending on the analysis and interpretation of the data, major findings were identified and presented} as follows:

- The Teacher's Performance Appraisal system used for teachers learning and growth as indicated by the majority of respondents in wolaita zone preparatory schools was for motivation or career structure and for the sake of reporting for higher bodies with weighted mean 3.0and 4.17respectively . On the other hand, assigning performance appraisal committee on merit bases, identifying training needs, stimulate teachers to 
think consciously about learning and growth ,involves stakeholders in teachers performance appraisal to bring quality of teaching learning were rated as very low with weighted mean value $1.81,2.33,1.65,1.96$ and 2.02 respectively .

- As reported by the majority of appraisers and appraises, the methods of performance appraisal commonly used for implementation of teachers performance in preparatory schools were summative evaluation method and check list with weighted mean values 3.46 and 3.26. But the other methods of teachers' performance appraisals like peer evaluation methods, self-evaluation method, and formative evaluation methods were not frequently used as indicated by majority of respondents very low with weighted mean values 1.82 and 2.06 respectively.

- As represented by majority respondents $47 \%$ and $54 \%$ the performance appraisal methods used in preparatory schools lead teachers in to low level of satisfaction as well as affects individuals efficiency as reported by majority of respondents.

- Appraising teacher's performance appraisal in preparatory school was the responsibility of principals, vice principals. Whereas the involvement of department heads, students and teachers were low Stripped

- The great numbers of respondents reported that the extent to which the principals involve stakeholders in teacher's performance appraisal was nonexistent. It is somewhat deviated from performance appraisal purpose because attitude of school leaders had no habit of assigning performance appraisal committee.

- According to the result criteria employed in appraising teachers' performance appraisal was result based criteria but schools do not use performance based criteria.

- As reported by the majority of appraisers and appraises, the criteria used to appraise teachers was unclear, does not measure good teaching, no capacity of Measuring teachers willingness to participate in extracurricular activities, not appropriate to raise teachers professional development.

- As reported by the majority of appraisers and appraises, the criteria describes what the teachers are, rather than what teachers does.

- The finding indicates that the teachers, who perform relatively better, were not rewarded.

- According to the result the major problems encountered in appraising the performance of preparatory schools teachers in wolaita zone were, lack of rewards for better performing teachers, lack of awareness about performance appraisal, In adequate guidance and support from higher official, and technical problems of principals for implementation.

\section{Conclusions}

Firstly, Performance appraisal is the ongoing process used for identifying, measuring and developing an individual's performance in accordance with an organization's Strategic goals (Aguinis, 2009). Appraisal may involve formative aspects that focus on developing performance, such as career development, professional learning and feedback.

Summative aspects, on the other hand, evaluate performance for career progression, possible promotion or demotion and termination purposes. In connection to this, the study reviled that the extent of teacher's performance appraisal that used for teachers learning and growth was for only motivation like career structure and for the sake of reporting purpose .Contrary to this concept, the real situation in secondary schools of Wolaita zone, as per the result of the finding, the extents of teachers performance appraisal used for teachers learning and growth was low. Thus, it is safe to conclude that the teaching learning process is not supplemented by the performance appraisal result and thereby no quality instruction is delivered in the secondary schools of the zone.

Secondly, the implementation of Teachers' Performance Appraisal system in wolaita zone preparatory schools were use restricted methods like checklist to assess teachers performance appraisal but most of preparatory school leaders do not use peer-evaluation methods, formative evaluation and self-evaluation method so that appraisal methods in this zone lead teachers in to low level of satisfaction as well as the performance appraisal method affects individuals efficiency and organizational goals. According to Webb and Norton (1992) and Duke (1995) Formative evaluation is a continuous evaluation process which is aimed at providing constructive feedbacks to the employee assuming self-improvement as a core purpose. This type of evaluation creates opportunities to address issues related to employees' continual professional development rather than administrative decisions.

Finally, the Criteria Employed in Appraising Teachers' Performance Appraisal was result based rather than performance based criteria. It means that the criteria employed to appraise teachers Performance in wolaita zone preparatory schools was lost clarity, does not measure good teaching un participative and describe what the teachers are, rather than what the teacher dose.

\section{Recommendations}

- The study shows that the TPA criteria currently used to appraise teachers ${ }^{\text {ee }}$ performance are found to be 
inadequate and inappropriate to appraise the performance of teacher's in secondary and preparatory school of wolaita zone. This is why that no involvement of stakeholders preparation of performance criteria. According the training manuals of some writers, the training manual document stated that, the employee must be fully involved in developing the appraisal criteria. But in practice, teachers involved only in giving comments on what is already developed. Merely administrator of education is the determinant bodies to prepare performance criteria. This practice violated the principle of teacher participation. So it is better to reach at consensus on the participation of teachers and principals in designing, reviewing, and improving of TPA criteria. So, wolaita zone education office has to take this into account. As a result every one becomes more accountable and the system becomes more responsive to the need of all constituents.

- The findings of the study shows that teachers who perform better relative to others were not rewarded. The stakeholders in secondary and preparatory school of wolaita zone should identify individual teachers' strengths and weaknesses, and have to give reward to that that performed better as much as possible.. Otherwise this may negatively affect work morals of teachers and that can result negative perceptions on the appraisal system implemented in the schools .So, the zone education office, the Woreda education officers and the school principals are responsible for these.

- $\quad$ For valid and reliable performance appraisal purposes teachers' performance must be continuously reviewed and registered in diary form- By doing this performance defaults can be avoided on time and teachers ${ }^{\text {ce }}$ performance can be improved through counselling and mentoring. Hence, from the document reviews, checklist employed in secondary and preparatory schools understudy it was observed that only summative appraisals were used. Therefore, it is suggested that formative appraisal and summative appraisal ought to be separated and treated in two different performance checklists; and adequate training on how to conduct formative and summative appraisal separately should be given to school principals and vice principals. The officials of education must follow up the practice every time.

- It is recommended that zonal and woreda education offices should plan training for its appraisers i.e. principals, department heads, unit leaders and teachers so as to enable them acquire adequate knowledge and skill; and to acquaint them with the purposes, criteria, process and procedures of TPA scheme; and the methods of observation, data collection and other relevant issues of the appraisal scheme. This will minimize the error occurred in PA process and will enhance the confidence of teachers to the value and to accept the performance appraisal system. In addition, emphasis should be given to the assignment of principals by zonal and woreda education offices on their strength to the particular position. Therefore, it would be wise if graduates of Educational leadership or those who have at least skill and knowledge of teachers' performance appraisal system or human resource managerial skill are assigned to run the government secondary and preparatory schools of wolaita zone.

\section{References}

Armstrong, M. and Baron, A. 2002. Performance Management. The new realities, Institute of Personnel and Development, London, U.K

Berhanu Moyata (2006). Implementation of Result-oriented teachers' performance as Appraisal, perceived by principals and teachers (unpublished master's thesis), Addis Ababa University.

Duke, D.L. (1995). Teacher's Evaluation Policy from Accountability to Professional development. New York: state university of New York press, Albany

Hailesilasie Waldagerima.1999. Human Resource Management. A Teaching Material: Addis Ababa University, Addis Ababa, Ethiopia.

Ivancevich, J.M. (2004). Human Resource Management. 9th edition, McGraw- Journal of Management History, $4(3), 233-249$.

Mathis, R.L. \& Jackson, J.H. (1997). Human Resource Management. (8th Ed.). USA: West publishing company.

McCrea, Thomas. L. (1984). Successful teacher evaluation. Alexandria, VA: Association.

Melaku Yimam (1992) "Appraiser-Apraisee Perception of Teachers' Performance Appraisal". A.A.U. (Unpublished Masters' Thesis).

Melaku Yimam (2000). Human Resource Management in Education. Addis Ababa University. (Unpublished Teaching Material).

Rasheed, M.I., Sarwar, S and Aslam, H.D. 2013. A Critical Analysis of Performance Appraisal System for Teachers in Public Sector Universities of Pakistan: A Case Study of Islamia University of Bahawalpur. African Journal of Business Management 5(9):335-34.

Stronge, J. H. (2006). Evaluating teaching: A guide to current thinking and best practice 2 nd ed. Thousand Oaks, CA: Corwin Press.

Stronge, J.H. \& Tucker, P.D. (1999). The politics of teacher evaluation: A case study of new system design and implementation. Journal of Personnel Evaluation in Education, 13(4),339-360.

Stronge, J. H., \& Tucker, P. D. (2003). Handbook on teacher evaluation: Assessing and improving performance. 
Larchmont, NY. Eye on Education Publications.

Tatek Abera. 2012. Performance Appraisal and Teachers Reaction in Secondary Schools of West Hararghe Zone. MEd Thesis, Haramaya University: Haramaya, Ethiopia.

Webb, L.D and Norton, MS (1992). Human Resources Administration. Personnel

Issues and Needs in Education

Yilma (2007). Practices of Teachers" Performance Appraisal the case of SNNPRS (unpublished master's thesis) Addis Ababa University. 